\title{
IN VITRO EVALUATION OF SELECTED FUNGICIDES AND SOME PLANT EXTRACTS AGAINST SEED-BORNE FUNGI OF SESAME (SESAMUM INDICUM L.)
}

\author{
Md. Delwar Hosen and Shamim Shamsi* \\ Department of Botany, University of Dhaka, Dhaka-1000, Bangladesh
}

Key words: Fungicides, Plant extracts, Seed borne fungi, Sesame seeds

Two pathogenic fungi Aspergillus niger van Tiegh, and Fusarium merismoides Corda were isolated from sesame seeds. Five fungicides viz., Bavistin DF, Capvit 50 WP, Dithane M-45, Ridomil Gold MZ 68 WG and Tilt 250 EC were selected to evaluate their in vitro efficacy at 100 , 200, 300, 400 and $500 \mathrm{ppm}$ concentrations against A. niger and F. merismoides. Out of five fungicides Bavistin DF showed the complete growth inhibition of A. niger and $F$. merismoides at $100 \mathrm{ppm}$ concentration. Tilt $250 \mathrm{EC}$ also showed the complete growth inhibition of $F$. merismoides at $100 \mathrm{ppm}$ concentration. Ethanol extracts of five plant parts were selected to evaluate their in vitro fungitoxicity at $5,10,15$ and $20 \%$ concentrations against the test pathogens. In the present study, out of the five plants extract, A. sativum showed complete growth inhibition of both the test pathogens. Bavistin DF and Tilt $250 \mathrm{EC}$ found to be the best inhibiting fungicide while A. sativum as the best plant extract for further testing against seed borne fungi of sesame.

In Bangladesh, sesame is the important summer oilseed crop occupying $9.4 \%$ of the total oilseed area (BBS 2012). Sesame is highly beneficial as it contains $42-50 \%$ oil and the oil contains $42 \%$ essential linoleic acid, $25 \%$ protein and $16-18 \%$ carbohydrate. The seed on an average, consists of $47 \%$ oil and $20 \%$ protein (Rahman 1976). The oil is consumed largely as a cooking and salad oil. Stem rot and Cercospora leaf spot of sesame has been reported from Bangladesh. Pre-sowing seed dressing with fungicides like Vitavax-200 was found effective in reducing the seed borne pathogen and also enhance the germination percentage of the seeds. Cercospora leaf spot was reduced with Bavistin $(0.1 \%)$ or Dithane M-45 $(0.2 \%)$. Chemical pesticides could control diseases and result in improved yield. However, indiscriminate use of pesticides could produce environmental and health hazards. Appropriate technology might result in more effective use of natural resources in agriculture. Plant extracts could be useful in modern agriculture for disease management. The control of plant pathogens by their use is becoming important day by day over chemical methods of controlling plant diseases, based on fungicides. Plant parts and their constituents of some higher plants have already been reported to be successful fungitoxicants (Ahmed et al. 2013). Present investigation was undertaken to evaluate efficacy of some selected fungicides and plant extracts against two pathogens of sesame.

Two varieties of sesame (Sesamum indicum L.) seeds, namely BARI Til-3, BARI Til-4, were collected from the Bangladesh Agricultural Research Institute (BARI), Joydebpur, Gazipur, Bangladesh. The experiment was conducted in the Laboratory of Mycology and Plant Pathology,

*Author for correspondence: <prof.shamsi@gmail.com>. 
Department of Botany, University of Dhaka, Bangladesh from May, 2015 to July, 2016. Quality status of two varieties of sesame seeds were determined by seed quality analysis ISTA (Anon. 1976 and 2014).

Five fungicides i.e., Bavistin DF, Capvit $50 \mathrm{WP}$, Dithane M-45, Ridomil MZ Gold and Tilt $250 \mathrm{EC}$ at 100, 200, 300, 400 and $500 \mathrm{ppm}$ were used to evaluate their in vitro efficacy against test pathogens. Five higher plants were selected to evaluate their in vitro efficacy against test pathogens. Ethanol extract of Allium sativum L. (bulb), Azadirachta indica A. Juss. (leaf), Citrus limon (L.) Burm. f. (leaf), Mangifera indica L. (leaf) and Psidium guajava L. (leaf) at 5, 10, 15 and $20 \%$ were used to evaluate their in vitro efficacy against test pathogens, A. niger and $F$. merismoides. In vitro evaluation of fungicides and plant extracts against test pathogens were carried out by 'poison food technique' following Shamim. and Chowdhury ( 2016 ).

A total of 9 species of fungi viz. Aspergillus flavus, A. fumigatus, A. niger, Curvularia lunata, Fusarium merismoides, Mucor sp., Penicillium sp., Rhizopus stolonifer and Trichoderma viride were isolated and identified from sesame seeds. All the isolated fungi were tested for their pathogenic potentiality following seed inoculation technique (Chowdhury et al. 2015). Among the isolated fungi A. niger, was found to be pathogenic to both the sesame varieties studied and F. merismoides was found to be pathogenic to seeds of BARI Til-3.

All the fungicides inhibited the radial growth of the two test pathogens A. niger and $F$. merismoides. The extent of growth inhibition, however, varied amongst the fungal isolates. $A$. niger and $F$. merismoides were completely inhibited by Bavistin DF at the concentrations of 100, 200, 300, 400 and $500 \mathrm{ppm}$. Tilt $250 \mathrm{EC}$ also completely inhibited radial growth of $F$. merismoides at the same concentrations. Chakraborty et al. (2009) reported that, at 5\% conc., Bavistin happened to be the most efficient on Fusarium solani causing wilt of brinjal. Bashar (1992) reported the results of laboratory evaluation of some fungicides on $F$. oxysporum f. sp. ciceri causing wilt of chickpea found that Bavistin could control the pathogen completely at 100 ppm concentration. Results of the experiments are presented in Tables 1 and 2.

Table 1. Per cent inhibition of radial growth of Aspergillus niger at different conc. of fungicides.

\begin{tabular}{llllll}
\hline Name of & \multicolumn{5}{c}{$\%$ inhibition of radial growth at different concentrations (ppm) } \\
\cline { 2 - 6 } fungicides & 100 & 200 & 300 & 400 & 500 \\
\hline Bavistin DF & $100^{\mathrm{a}}$ & $100^{\mathrm{a}}$ & $100^{\mathrm{a}}$ & $100^{\mathrm{a}}$ & $100^{\mathrm{a}}$ \\
Capvit 50 WP & $0.0^{\mathrm{NS}}$ & $0.0^{\mathrm{NS}}$ & $0.0^{\mathrm{NS}}$ & $0.0^{\mathrm{NS}}$ & $0.0^{\mathrm{NS}}$ \\
Dithane M-45 & $43.82^{\mathrm{a}}$ & $52.62^{\mathrm{a}}$ & $56.18^{\mathrm{a}}$ & $57.30^{\mathrm{a}}$ & $60.67^{\mathrm{a}}$ \\
Ridomil MZ Gold & $47.75^{\mathrm{a}}$ & $53.37^{\mathrm{a}}$ & $70.00^{\mathrm{a}}$ & $100^{\mathrm{a}}$ & $100^{\mathrm{a}}$ \\
Tilt 250 EC & $87.08^{\mathrm{a}}$ & $88.76^{\mathrm{a}}$ & $92.70^{\mathrm{a}}$ & $97.75^{\mathrm{a}}$ & $98.88^{\mathrm{a}}$ \\
\hline
\end{tabular}

Remarks efficiency gradient: Bavistin DF > Ridomil MZ Gold > Tilt > Dithane M-45 > Capvit 50 WP. $\mathrm{a}, \mathrm{b}$ and $\mathrm{c}$ indicate significance at $0.1,1$ and $5 \%$ level, respectively. In a row, figures with same letter do not differ significantly whereas figures with dissimilar letter differ significantly (as per DMRT), NS = Not significant. 
Capvit 50 WP showed maximum (70.09\%) growth inhibition of $F$. merismoides at $400 \mathrm{ppm}$ concentration. Complete inhibition of $F$. merismoides occurred at $500 \mathrm{ppm}$ concentration. Capvit 50 WP had no effect on $A$. niger.

Dithane M-45 showed the highest (60.61\%) growth inhibition of A. niger at $500 \mathrm{ppm}$. The same fungicides showed $43.48 \%$ growth inhibition of $F$. merismoides at 500 ppm conc..

Ridomil MZ Gold showed maximum (70.00\%) growth inhibition of A. niger at $300 \mathrm{ppm}$, Aspergillus niger was completely controlled by the same fungicide at 400 and $500 \mathrm{ppm}$ concentrations.

Table 2. Per cent inhibition of radial growth of Fusarium merismoides at different conc. of fungicides.

\begin{tabular}{llllll}
\hline Name of & \multicolumn{5}{c}{ \% inhibition of radial growth at different concentrations (ppm) } \\
\cline { 2 - 6 } fungicides & 100 & 200 & 300 & 400 & 500 \\
\hline Bavistin DF & $100^{\mathrm{a}}$ & $100^{\mathrm{a}}$ & $100^{\mathrm{a}}$ & $100^{\mathrm{a}}$ & $100^{\mathrm{a}}$ \\
Capvit 50 WP & $42.31^{\mathrm{b}}$ & $47.44^{\mathrm{b}}$ & $51.28^{\mathrm{a}}$ & $70.09^{\mathrm{a}}$ & $100^{\mathrm{a}}$ \\
Dithane M-45 & $20.51^{\mathrm{c}}$ & $26.92^{\mathrm{b}}$ & $32.05^{\mathrm{b}}$ & $35.90^{\mathrm{b}}$ & $45.30^{\mathrm{b}}$ \\
Ridomil MZ Gold & $28.57^{\mathrm{b}}$ & $34.28^{\mathrm{b}}$ & $37.14^{\mathrm{b}}$ & $42.86^{\mathrm{b}}$ & $45.71^{\mathrm{b}}$ \\
Tilt 250 EC & $100^{\mathrm{a}}$ & $100^{\mathrm{a}}$ & $100^{\mathrm{a}}$ & $100^{\mathrm{a}}$ & $100^{\mathrm{a}}$ \\
\hline
\end{tabular}

Remarks efficiency gradient: Bavistin $=$ Tilt $>$ Capvit $>$ Ridomil $>$ Dithane.

$\mathrm{a}, \mathrm{b}$ and $\mathrm{c}$ indicate significance at $0.1,1$ and 5\% level, respectively. In a row, figures with same letter do not differ significantly whereas figures with dissimilar lettet differ significantly (as per DMRT), NS $=$ Not significant.

Table 3. Effects of plant extracts on the radial growth of Aspergillus niger at different concentrations.

\begin{tabular}{|c|c|c|c|c|c|}
\hline \multirow{2}{*}{$\begin{array}{l}\text { Sl. } \\
\text { No. }\end{array}$} & \multirow{2}{*}{ Name of plant } & \multicolumn{4}{|c|}{$\%$ inhibition of radial growth of the pathogen at different conc. (\%) } \\
\hline & & 5 & 10 & 15 & 20 \\
\hline 1. & Allium sativum & $100^{\mathrm{a}}$ & $100^{\mathrm{a}}$ & $100^{\mathrm{a}}$ & $100^{\mathrm{a}}$ \\
\hline 2. & Azadirachta indica & $64.04^{\mathrm{a}}$ & $66.29^{\mathrm{a}}$ & $67.42^{\mathrm{a}}$ & $82.02^{\mathrm{a}}$ \\
\hline 3. & Citrus limon & $74.16^{\mathrm{a}}$ & $78.65^{\mathrm{a}}$ & $79.78^{\mathrm{a}}$ & $80.90^{\mathrm{a}}$ \\
\hline 4. & Mangifera indica & $0.0^{\mathrm{NS}}$ & $67.98^{\mathrm{a}}$ & $70.79^{\mathrm{a}}$ & $74.16^{\mathrm{a}}$ \\
\hline 5. & Psidium guajava & $0.0^{\mathrm{NS}}$ & $0.0^{\mathrm{NS}}$ & $0.0^{\mathrm{NS}}$ & $75.84^{\mathrm{a}}$ \\
\hline
\end{tabular}

Remarks of efficiency gradient of Aspergillus niger : Allium sativum >Citrus limon >Azadirachta indica Mangifera indica > Psidium guajava.

$\mathrm{a}, \mathrm{b}$ and $\mathrm{c}$ indicate significance at $0.1,1$ and $5 \%$ level, respectively. In a row, figures with same letter do not differ significantly whereas figures with dissimilar lettet differ significantly (as per DMRT), NS = Not significant.

Tilt 250 EC showed maximum $98.88 \%$ growth inhibition of A. niger at 500 ppm. Fusarium merismoides was completely inhibited at 100 concentration by the same fungicide. (Tables 1 and 2).

The order of effectiveness of fungicides at $500 \mathrm{ppm}$ concentration against $A$. niger were Bavistin BF > Ridomil MZ Gold > Tilt 250 EC Dithane > M-45 > Capvit 50 WP. The order of 
effectiveness of funicides against $F$. merismoides at $500 \mathrm{ppm}$ concentration were Bavistin $\mathrm{BF}>$ Capvit 50 WP > Tilt 250 EC > . Ridomil MZ Gold > Dithane > M-45 .

In vitro evaluation of fungicides revealed that except Capvit all the fungicides showed complete/partial inhibition of $A$. niger and F. merismoides at $500 \mathrm{ppm}$.

All the five plant extracts showed fungitoxicity against both the test pathogens (Table 3 and 4). The most promising fungitoxic effect was recorded in case of $A$. sativum against $A$. niger and F. merismoides. Efficacy of A. sativum extracts in controlling seed-borne fungal infection in different crops has also been reported by Meah et al. (2004) and Rashid et al. (2007).

Table 4. Effects of plant extracts on the radial growth of Fusarium merismoides at different concentrations.

\begin{tabular}{llcccc}
\hline \multirow{2}{*}{$\begin{array}{l}\text { S1. } \\
\text { No. }\end{array}$} & \multirow{2}{*}{$\begin{array}{l}\text { Name of } \\
\text { plant }\end{array}$} & \multicolumn{4}{c}{$\%$ inhibition of radial growth of the pathogen at different conc. $(\%)$} \\
\cline { 2 - 5 } & 5 & 10 & 15 & 20 \\
\hline 1. & Allium sativum & $100^{\mathrm{a}}$ & $100^{\mathrm{a}}$ & $100^{\mathrm{a}}$ & $100^{\mathrm{a}}$ \\
2. & Azadirachta indica & $60.00^{\mathrm{b}}$ & $67.50^{\mathrm{a}}$ & $71.25^{\mathrm{b}}$ & $80.42^{\mathrm{b}}$ \\
3. & Citrus limon & $34.94^{\mathrm{b}}$ & $54.22^{\mathrm{b}}$ & $77.11^{\mathrm{a}}$ & $100^{\mathrm{a}}$ \\
4. & Mangifera indica & $25.00^{\mathrm{c}}$ & $28.57^{\mathrm{c}}$ & $39.29^{\mathrm{b}}$ & $50.00^{\mathrm{b}}$ \\
5. & Psidium guajava & $28.57^{\mathrm{c}}$ & $35.71^{\mathrm{b}}$ & $46.43^{\mathrm{b}}$ & $53.57^{\mathrm{b}}$ \\
\hline
\end{tabular}

Remarks of efficiency gradient of Fusarium merismoides: Allium sativum >Citrus limon >Azadirachta indica $>$ Psidium guajava $>$ Mangifera indica.

$\mathrm{a}, \mathrm{b}$ and $\mathrm{c}$ indicate significance at $0.1,1$ and 5\% level, respectively. In a row, figures with same letter do not differ significantly whereas figures with dissimilar lettet differ significantly (as per DMRT), NS = Not signific.

The order of effectiveness of plant parts extracts against A. niger at $20 \%$ concentration was Allium sativum (100\%) >Azadirachta indica (82.02\%) > Citrus limon (80.90\%) > Psidium guajava $(75.84 \%)>$ Mangifera indica $(74.16 \%)$.

The order of effectiveness of plant parts extracts against $F$. merismoides at $20 \%$ concentration was Allium sativum and Citrus limon (100\%) > Azadirachta indica (80.42\%) > Psidium guajava $(53.57 \%)>$ Mangifera indica $(50.0 \%)$. Mamun et al. (2016) reported that the plant extracts of Allium sativum, Azadirachta indica and Citrus limon showed growth inhibitory role on $F$. oxysporum at the same concentration.

Extracts of Azadirachta indica and Citrus limon were moderately effective while extracts of Mangifea indica and Psidium guajava were slightly effective in controlling the test pathogens. Rahman et al. (1999) also found moderate effect of neem extract against fungi associated with wheat seeds. The study suggested that fungitoxicity of the plant extracts that have been found to be promising against both the pathogens associated with sesame seeds. Chakraborty et al. (2009) reported that the efficacy of various plant extracts against the growth plant of the plant. 
Bavistin DF and Tilt $250 \mathrm{EC}$ were found to be the best inhibiting agent against the in vitro growth of the sesame pathogens. Considering plant extracts A. sativum was found to be effective against $A$. niger and $F$. merismoides.

\section{References}

Ahmed, M., M. Hossain, K. Hassan and C.K. Dash. 2013. Efficacy of different plant extracts on reducing seed-borne infection and increasing germination of collected rice seed sample, Universal Journal of Plant Science 1(3): 66-73.

Anonymous. 1976. International Rules for Seed Testing Proc. Int. Seed Test. Ass. 4: 3-49.

Anonymous. 2014. International Rules for Seed Testing. Int. Seed Test. Ass. Switzerland. pp. 10.

Bashar, M.A. 1992. Laboratory evaluation of some pesticides on Fusarium oxysporum f. sp. ciceri causing wilt of chickpea. Bangladesh J. Bot. 21(1): 157-159.

BBS. 2012. Statistical Yearbook of Bangladesh. $23^{\text {rd }}$ Edn, Statistics Division. Ministry of Planning, Govt. of the People's Rep. of Bangladesh, Dhaka 317: 97-98.

Chakraborty M.R., N.C, Chatterjee and and T.H. Quimio. 2009. Integrated management of fusarial wilt of eggplant (Solanum melongena) with soil solarization. Micologia Aplicada International. 21(1): 25-36.

Chowdhury, P., M.A. Bashar and S. Shamsi. 2015. In vitro evaluation of fungicides and plant extracts against pathogenic fungi of two rice varieties. Bangladesh J. Bot. 44(2): 251-259.

Mamun, M. A., S. Shamsi and M.A. Bashar. 2016. In vitro evaluation of fungicides and plant extracts against pathogenic fungi of jute seeds. Bioresearch Communications 2(1):189-192.

Meah, M.B., M.R. Islam and M.M. Islam 2004. Development of an integrated approach of management of Phomopsis blight and fruit rot of eggplant in Bangladesh. Annual Research Report, Department of Plant Pathology, BAU, Mymensingh, Bangladesh. pp. 57.

Rahman, G.M.M., M.R. Islam and M.A. Wadud. 1999. Seed treatment with plant extracts and hot water: a potential biophysical method of controlling seed-borne infection of wheat. Bangladesh J. Train. Dev. 12(1\&2): 185-190.

Rahsid, M.M., M.M.R. Khan, M.A, Hossain and M.M. Hossain. 2007. Management of seed-borne fungi of jute in Mymensingh region. Bangladesh J. Crop Sci. 18(1): 209-214.

Shamim, S. and P. Chowdhury. 2016. In vitro evaluation of fungicides and some plant extracts against rice shaeath rot pathogen Sarocladium oryzae. Bangladesh J. Sci. Res. 29(1): 47-54.

(Manuscript received on 1 January, 2018; revised on 21 February, 2018) 